\title{
Facebook® and academic performance
}

\author{
Citation for published version (APA):
}

Kirschner, P. A., \& Karpinski, A. (2010). Facebook ${ }^{\circledR}$ and academic performance. Computers in Human Behavior, 26(6), 1237-1245. https://doi.org/10.1016/j.chb.2010.03.024

DOI:

10.1016/j.chb.2010.03.024

Document status and date:

Published: 04/11/2010

Document Version:

Peer reviewed version

\section{Document license:}

CC BY-SA

Please check the document version of this publication:

- A submitted manuscript is the version of the article upon submission and before peer-review. There can be important differences between the submitted version and the official published version of record. People interested in the research are advised to contact the author for the final version of the publication, or visit the DOI to the publisher's website.

- The final author version and the galley proof are versions of the publication after peer review.

- The final published version features the final layout of the paper including the volume, issue and page numbers.

Link to publication

\section{General rights}

Copyright and moral rights for the publications made accessible in the public portal are retained by the authors and/or other copyright owners and it is a condition of accessing publications that users recognise and abide by the legal requirements associated with these rights.

- Users may download and print one copy of any publication from the public portal for the purpose of private study or research.

- You may not further distribute the material or use it for any profit-making activity or commercial gain

- You may freely distribute the URL identifying the publication in the public portal.

If the publication is distributed under the terms of Article 25fa of the Dutch Copyright Act, indicated by the "Taverne" license above, please follow below link for the End User Agreement:

https://www.ou.nl/taverne-agreement

Take down policy

If you believe that this document breaches copyright please contact us at:

pure-support@ou.nl

providing details and we will investigate your claim.

Downloaded from https://research.ou.nl/ on date: 26 Apr. 2023 


\author{
Running head: FACEBOOK ${ }^{\circledR}$ AND ACADEMIC PERFORMANCE \\ Facebook $^{\circledR}$ and Academic Performance \\ Paul A. Kirschner ${ }^{1} \&$ Aryn C. Karpinski ${ }^{2}$ \\ ${ }^{1}$ Open University of the Netherlands \\ ${ }^{2}$ The Ohio State University
}

Corresponding author:

Prof. dr. Paul A. Kirschner, Centre for Learning Sciences and Technologies (CELSTEC), Open University of the Netherlands, Valkenburgerweg 177, 6419AT Heerlen, The Netherlands, +3145 5762361, paul.kirschner@ou.nl 


\begin{abstract}
There is much talk of a change in modern youth - often referred to as digital natives or Homo Zappiens - with respect to their ability to simultaneously process multiple channels of information. In other words, kids today can multitask. Unfortunately for proponents of this position, there is much empirical documentation concerning the negative effects of attempting to simultaneously process different streams of information showing that such behavior leads to both increased study time to achieve learning parity and an increase in mistakes while processing information than those who are sequentially or serially processing that same information. This article presents the preliminary results of a descriptive and exploratory survey study involving Facebook use, often carried out simultaneously with other study activities, and its relation to academic performance as measured by self-reported Grade Point Average (GPA) and hours spent studying per week. Results show that Facebook ${ }^{\circledR}$ users reported having lower GPAs and spend fewer hours per week studying than nonusers.
\end{abstract}




\section{Facebook $^{\circledR}$ and Academic Performance}

We read it every day in the newspapers, hear it constantly on the news, and thanks to our Really Simple Syndication (RSS) feeds, we also get it 24/7 online. The "it" is the news about today's children who are spoiled, love luxury, have bad manners, have contempt for authority, are disrespectful to their elders, contradict their parents, and tyrannize their teachers. We also are constantly being reminded of the fact that the world is passing through troubling times, and that young people today think of nothing but themselves, are impatient, talk as if they know everything, and what passes for wisdom for us is foolishness for them. The only problem with the aforementioned is that the first statement was uttered by Socrates, sometime around $300 \mathrm{BCE}$ and the second statement was uttered by Peter the Hermit, a priest of Amiens and a key figure during the First Crusade, who died July 8, 1115 in Neufmoutier by Huy in Belgium.

A glance in the myriad of scientific journals, academic book sellers, and web sites cannot help but make us think that today's generation of children is radically different from its predecessors. It appears that the Baby Boomers have spawned Generation X, the MTV generation, Net Geners, Millenials, Generation Y / iGeneration, and even generation Z (Howe \& Strauss, 2000; Oblinger \& Oblinger, 2005; Prensky, 2001; Rosen, 2007; Tapscott, 1998). At a recent conference of the Western Psychological Association (i.e., April 23-26, 2009 in Portland Oregon), Rosen defined these children as follows:

Welcome to the Net Generation. Born in the 1980s and 1990s, they spend their days immersed in a "media diet" accumulating a fulltime job plus overtime devouring entertainment, communication, and every form of electronic media. They are master multitaskers, social networkers, electronic communicators and the first to rush to any new technology. They were born surrounded by technology and with every passing year they 
add more tools to their electronic repertoire. They live in social networks such as Facebook, MySpace, and Second Life gathering friends; they text more than they talk on the phone; and they Twitter the night away often sleeping with their cell phones vibrating by their sides.

The assumption is that these children now have acquired specific new multitasking skills that they are able to apply in a learning setting, and that education as we know it is frustrating them in the application of these multitasking skills. Unfortunately, most empirical research shows that this is not the case finding either that (1) children do not possess these skills, or (2) that acting in this way negatively affects the processing of information. This article first tackles these two widely-held, modern-day "truths," and then presents the results of a preliminary study on the potential relationship between Facebook ${ }^{\circledR}$ (FB) and academic performance.

We Hold These Truths to be Self-evident

We see children today doing their homework, watching YouTube ${ }^{\circledR}$, instant messaging (IM), Twittering, using FB, surfing websites, and so forth in a way that seems as if they are doing all of this simultaneously. In other words, today's learners are multitasking homo zappiens (Veen \& Vrakking, 2006). Consequently, the assumption is made that these children are also able to do all of this effectively, efficiently, and without a loss to the present task. But is this so? Is the youth of today a homo zappien, and can children, adolescents and emerging adults really multitask?

\section{Homo Zappiens}

Wim Veen proposed the term Homo Zappiens, referring to the new generation of learners who, according to him, unlike their predecessors, learn in a considerably different way. According to 
Veen and Vrakking (2006), children belonging to this generation develop - on their own and without instruction - the meta-cognitive skills necessary for enquiry-based learning, discoverybased learning, networked learning, experiential learning, collaborative learning, active learning, self organization and self regulation, problem solving, and making their own implicit (i.e., tacit) and explicit knowledge specific to others. In addition, Beastall (2008) stated that the current generation of children and young adults have an advanced relationship with technology that is formed at birth. Prensky (2001) noted their familiarity with and reliance on Information and Communication Technology (ICT), describing them as living lives immersed in technology, "surrounded by and using computers, videogames, digital music players, video cams, cell phones, and all the other toys and tools of the digital age" (p. 1). He argues that children and young adults today, due to their relationship with technology from birth, have an innate technological competence that can be characterized as multitasking (i.e., parallel processing functions; Prensky, 2003). The author also details that even very young children are developing multitasking strategies via technological familiarity that enable them to navigate novel spatial environments, and recognize and manipulate visual images. Overall, according to Prensky (2003), encounters with technology can allow young children to have experience with how sounds, images and texts interact, which may be crucial to early schooling success and overall development in this digital world.

But does such an information technology-savvy generation actually exist? Owens (2004a, 2004b), Director of Learning at the United Kingdom's (UK) Nesta Futurelab, has shown that the majority of children in advanced economies spend less than 30 minutes a day on the computer. Additionally, the main demographic for computer game playing is 20 to 35 year-olds, and in the United States, the highest usage of the Internet at home is among 35 to 44 year-olds (National 
Telecommunications and Information Administration, 2000). More recently, Margaryan and Littlejohn (2008) reported that current university students (i.e., those in the Net generation) use a limited range of technologies for learning and socialization. They state:

For learning, mainly established ICTs are used - institutional VLEs [Virtual Learning Environment], Google and Wikipedia, and mobile phones...the findings point to a low level of use of and familiarity with collaborative knowledge creation tools, virtual worlds, personal web publishing, and other emergent social technologies (p. 1).

A number of recent research studies (Bullen, Morgan, Belfer, \& Quayuml, 2008; Ebner, Schiefner, \& Nagler, 2008; Kennedy et al., 2007; Kvavik, 2005) in different countries (e.g., Austria, Australia, Canada, Switzerland, the United States) question whether Homo Zappiens or Net Geners really exist. These researchers found that university students do not really have deep knowledge of technology, but that this is often limited to basic office suite skills, emailing, text messaging, FB, and surfing the Internet. According to Kvavik, students have basic office suite skills and can use email and surf the Internet with ease but "...moving beyond basic activities is problematic. It appears they do not recognize the enhanced functionality of the applications they own and use." (p. 7.7). He also states that "...significant further training in the use of information technology in support of learning and problem-solving skill..." is needed; "...[s]tudents appear to be slower developing adequate skills in using information technology in support of their academic activities which limits technology's current value to the institution" (p. 7.17). In a learning environment, functionality was limited to mostly passive consumption of information (e.g., Wikipedia $\left.{ }^{\circledR}\right)$ or for downloading lecture notes.

The fact that children nowadays make use of many electronic devices and are called digital natives does not make them good users of the media that they have at their disposal. First, 
they are capable of playing with technology, but not really using it efficiently (Bullen et al., 2006; Kvavik, 2005). They can Google ${ }^{\circledR}$, but lack the information skills to effectively find the information they need, and they also do not have the knowledge to adequately determine the relevance or truth of what they have found. This leads to essays on Baconian science (i.e., Francis Bacon, the $16^{\text {th }}$-century natural philosopher) with texts about the $20^{\text {th }}$-century British artist Francis Bacon and on the problems that Martin Luther King had with Pope Leo X and Holy Roman Emperor Charles V (i.e., Martin Luther, the protestant reformer)!

\section{Multitasking}

Multitasking is the simultaneous execution of two or more processing activities at the same time. Because people see children do this, many have assumed one or both of the following: (1) They actually are multitasking, and/or (2) They are capable of doing this without any loss of efficiency or effectiveness. This belief is often larded with statements that this is different from what previous generations could do, and that there has been a specific evolution of their brains to allow this. First, human beings are not really capable of multitasking, but can, at best, switch quickly from one activity to another (Kirschner, Sweller, \& Clark, 2006; Sweller, Kirschner, \& Clark, 2007). Actually, we can only multitask that which is automated (i.e. when schemas have been automated), and where thinking does not play a role (e.g., chewing gum, walking, and talking at the same time; though even this sometimes leads to walking into streetlamps or falling off curbs).

What people are really suggesting is that the current generation has, through practice, developed the ability to quickly switch between different tasks or different media. Unfortunately, this does not mean that it is beneficial or positive for them to do this or for learning in this way. It has been broadly shown that such rapid switching behavior, when compared to carrying out 
tasks serially, leads to poorer learning results in students and poorer performance of tasks (American Psychological Association, 2006). This is primarily due to the fact that switching requires a person to juggle her or his limited cognitive resources to accomplish the different tasks successfully. This juggling leads to greater inefficiency in performing each individual task, namely that more mistakes are made, and it takes significantly longer as compared to sequential work (Ophira, Nass, \& Wagner, 2009). According to David Meyer, director of the Brain, Cognition and Action Lab at Michigan State (Willis, 2006),

If a teenager is trying to have a conversation on an e-mail chat line while doing algebra, she'll suffer a decrease in efficiency, compared to if she just thought about algebra until she was done. People may think otherwise, but it's a myth. With such complicated tasks [you] will never, ever be able to overcome the inherent limitations in the brain for processing information during multitasking.

In a learning setting, Cox, Rosen, and Crawford (2008) demonstrated that while reading comprehension of graduate students using IM during a reading task was equal to that of students not using IM, students using IM took significantly longer to complete the different comprehension tests, and also took notably longer to read the passage given to them than those not using IM. The differences in time ranged from 1.53 to 1.77 times as long for the tests and 1.66 times as long for the reading. In other words, though equal comprehension can be achieved, the time needed for this is significantly longer. The time difference is negligible for short texts as were used in the experiment (i.e., 5.53 minutes versus 3.33 minutes), but what might the time difference become if the assignment were a "normal" university reading assignment? Additionally, a negative relationship was found between time spent IMing and reading comprehension scores and overall reported GPA. 
Related to the previous study, a recent unpublished dissertation examined task performance under multitasking conditions through a controlled experimental design where participants were asked to work with one or two partners through online communication tools like IMing and Skype. The results indicated that there was deterioration of performance from single task to multitask, with decreased productivity when multitasking (Xu, 2008). Interestingly, participants in the multitask conditions perceived their performance as satisfactory, although their collaborators gave a lower ratings of the other's performance.

This is further supported by research in other areas and literature in other disciplines such as transportation and communication. Research in the popular media and in peer-reviewed journals alike caution about the effects of multitasking on performance, specifically driving. A recent article in Car and Driver examined driving performance while text messaging on cell phones (Austin, 2009). Focusing primarily on reaction time, the results demonstrated that when reading or constructing a text while driving, reaction time slowed considerably in younger and older test subjects. Unsurprisingly, the older test subject fared worse, who went more than four seconds before looking up while reading a text message at 35 miles per hour, and over three and a half seconds while texting at 70 miles per hour. At best, the older subject traveled an extra 90 feet past baseline performance, and at worst, went 319 feet farther after a stimulus indicated the driver should stop.

Strayer, Drews, and Crouch (2006) compared driving performance of those who talk on their cell phone and drunk drivers. In a controlled laboratory environment, the results showed that when drivers were communicating on a cell phone, their braking reactions were delayed, and they were involved in more traffic accidents compared to when they were not conversing on a cell phone. Drunk drivers behaved similarly, although demonstrating a more aggressive driving 
style. Overall, the impairments associated with using a cell phone while driving can be as profound as those associated with driving while drunk. Strayer and colleagues (e.g., Strayer \& Drews, 2007; Strayer, Drews, \& Crouch, 2006; Strayer, Drews, \& Johnston, 2003) state: ...cell phone drivers were more likely to fail to stop at four-way intersections and more likely to be involved in rear-end collisions than drivers not using a cell phone. In fact, even when cell phone drivers were directing their gaze at objects in the driving environment they often failed to see them because attention was directed elsewhere...talking on a cell phone creates a form of inattention blindness, muting driver's awareness of important information in the driving scene...compared hand-held and hands-free cell phones and found that the impairments to driving are identical... There was no evidence that hands-free cell phones were any safer to use while driving than hand-held devices (Strayer et al., 2006, p. 382).

Some research, however, has stressed that quality and productivity do not lack in the face of multitasking or interrupted work. For example, a study by Mark and colleagues (2008) examined the disruption costs (e.g., additional time to complete the task, stress) of interruptions on task performance. Results indicated that if the interruptions are related to the context at hand, then the interruptions are perceived as beneficial, although the disruption cost is the same as with interruptions that are not similar to the context. Additionally, it was found that interrupted work is performed faster, but at a price. Subjects in the interrupted conditions experienced a higher workload, more stress, higher frustration, more time pressure, and effort.

\section{Social-Networking Sites and Facebook ${ }^{\circledR}$}

Socializing via the Internet has become an increasingly important part of young adult life (Gemmill \& Peterson, 2006). Relative to the general population, adolescents and young adults 
are the heaviest computer and Internet users, primarily using it for completing school assignments (46\%), e-mail and/or instant messaging (36\%), and playing computer games (38\%; DeBell \& Chapman, 2006). Social networking sites (hereafter SNS) are the latest online communication tool that allows users to create a public or private profile to interact with people in their networks (Boyd \& Ellison, 2008). SNS can be defined as

...web-based services that allow individuals to: (1) construct a public or semi-public profile within a bounded system, (2) articulate a list of other users with whom they share a connection, and (3) view and traverse their list of connections and those made by others within the system (Boyd \& Ellison, 2008, p. 211).

One such website is Facebook ${ }^{\circledR}$, which was created by Mark Zuckerberg to help residential college and university students identify students in other residence halls. It is described as " $\ldots$ an online directory that connects people through social networks at colleges and universities" (Zuckerberg, 2005, p. 1). Websites such as MySpace ${ }^{\circledR}$ and the more popular FB have millions of registered users, with FB becoming the overwhelmingly more popular SNS (Gavin, 2009; Gonzalez, 2009, checkfacebook.com). Currently, as of December 2009, there are more than 350 million active users (http://www.facebook.com/press/info.php?statistics). See Figure 1 for the data as of December 7, 2009.

\section{****INSERT FIGURE 1 ABOUT HERE****}

FB's popularity raises questions about the website's impact on college student life (Barratt, Hendrickson, Stephens, \& Torres, 2005). After expanding FB use to individuals outside the college and university system, the age group experiencing the most growth was 25 to 34 year-olds, with an increase of 181\%, and the 35 and older group increased 98\% (Lipsman, 2007a). However, despite this growth in older age groups, FB remains primarily a college-age 
and emerging adult phenomenon. Aside from the 350 million active users, 50 percent of active users $\log$ on to FB in any given day, with more than 8 billion minutes spent on the website worldwide each day (http://www.facebook.com/press/info.php?statistics). In addition, application use consumes a fair amount of activity on the website. The current statistics include: (1) more than 2.5 billion photos uploaded each month, (2) more than 14 million videos uploaded each month, (3) more than 3.5 billion pieces of content (i.e., web links, news stories, blog posts, notes, photos) shared each week, (4) more than 3.5 million events created each month, and (5) more than 45 million active user groups existing. As evidenced above, Facebook is a popular time-consuming activity that undoubtedly has some impact on college student life.

\section{Technology, SNS, and Academic Performance}

Research has examined the general impact of technology on academic achievement and development of children and teens. Positive and negative effects of technology on achievement have been documented. Espinosa, Laffey, Whittaker, and Sheng (2006) investigated the role of technology in early childhood development using data from the Early Childhood Longitudinal Study. The results indicated that access contributed to the learning potential of the students, but the authors cautioned that parents should encourage the educational use of technology to improve academic achievement. Lei and Zhao (2005) researched the specifics of access, acknowledging that quantity is not as important as quality when it comes to technology use and student achievement. Specifically, when the quality of technology use is not closely monitored or ensured, computer use may do more harm than good to student achievement in school. In addition, technology that was found to have a positive impact on academic achievement, or technology with educational value, was not popular and used less frequently. 
Studies have also documented no relation between computer use and academic achievement. For example, no relationship was found between time spent on the computer at home and GPA in a sample of adolescents (Hunley, Evans, Delgado-Hachey, Krise, Rich, \& Schell, 2005). Other researchers have found that recreational Internet use is strongly correlated with impaired academic performance (Kubey, Lavin, \& Barrows, 2001). Approximately 10-15\% of study participants reported feeling not being in complete control of their Internet use, and that it has hurt their schoolwork. Students who reported Internet-caused schoolwork problems were found to have spent five times more hours online than those who did not, and they were also significantly more likely to report that their Internet use caused them to stay up late, get less sleep, and miss classes. Although not specifically mentioning FB, the authors conclude that it is not so much the Internet that causes these problems as the new social opportunities of the Internet. Students who reported academic problems were more likely to use the Internet for realtime social activities such as IM and chat rooms. Kubey and colleagues note that these social uses are what hold students captive, especially late at night.

Specific to FB use, Vanden Boogart (2006), in an unpublished Master's thesis, found that heavy FB use (i.e., more time spent on FB) is observed among students with lower GPAs, although no control variables were implemented in the analyses. Conversely, Kolek and Saunders (2008) found that there was no correlation between Facebook use and GPA in a sample of students from a public Northeast research university. More recently, an exploratory survey study reported a negative relationship between FB use and academic achievement as measured by self-reported GPA and hours spent studying per week (Karpinski \& Duberstein, 2009). Again, this study only implemented one control variable (i.e., student status as either undergraduate or graduate), and failed to control for other confounding variables such as university major. These 
data from the study will be re-analyzed and presented in the current paper based on suggestions and feedback from other researchers. In response to the aforementioned study, another group of researchers used the exploratory findings as a springboard for a publication where no relationship was found between FB use and GPA (Pasek, More, \& Hargittai, 2009). However, the overall consensus is that more research needs to be done, and that the questioned relationship between SNS and academic performance remains largely unanswered.

The investigation of this phenomenon is difficult due to the methodologies involved and definition and measurement of the variables of interest. Focusing solely on FB or SNS use, implementing a true experimental design may not be viable. For example, obtaining a naive population of subjects who has never encountered, used, or heard of FB is virtually unattainable, and finding volunteers who will agree not to use their SNS for extended periods of time may be even more difficult. Thus, the experimental design and methodologies needed to properly study the topic makes such research prohibitive, if not impossible. Alternatives such as controlling for random covariates or diverse demographics without a solid rationale based in accepted theory in quasi-experimental designs and/or correlational studies can produce spurious results as well. Therefore, using other designs can be wrought with problems.

At the more basic level of construct and nomological network definitions, more fundamental problems and questions arise - How should FB "use" be defined? Can it be measured dichotomously (i.e., Yes/No) and if not, along what scale should they be measured? Should a timeline of use be examined (e.g., When was the account adopted)? Should "use" be specified in minutes/hours per day/week? How can amount of time spent on FB be measured with the necessary precision, considering the fact that most current research in this area involves self-report surveys? 
The measurement of academic performance is equally convoluted. For instance, how is academic performance defined? Should GPA or letter equivalents (e.g., A, B, C, D, F) be used? If letter equivalents are used, how should they be coded? Are other measures involved in academic performance such as amount of time spent studying, and for what length of time should “time spent studying” be observed (e.g., one day, a week, a month)? Additionally, academic performance is conceptualized differently not only between schools, but also across states, and even countries. How can the construct of academic performance be accurately defined and measured with such diversity in operational definitions? Overall, the ephemeral nature of technological trends may not render enough stability to fully investigate certain phenomenon such as FB's relationship to academic performance and differences in the definitions of constructs make comparisons across studies nearly impossible (Karpinski, 2009).

Many qualitative reports from studies and articles have depicted an acknowledgement by SNS users, specifically FB users, that spending "too much time" on the website may be incongruent with academic success or success in other venues such as work. Several case studies producing related information on the amount of time dedicated to specific SNS have been published. In one qualitative article, a graduate student describes her experience with FB and the association between time spent using SNS and productivity at work. She states,

I soon found many of my student employees bringing laptop computers to work and spending most of their receptionist shifts logged into thefacebook.com. I was even spending 10 - 15 minutes during my office hours confirming my friendships with students on the site (Barratt, Hendrickson, Stephens, \& Torres, 2005, p. 3).

The graduate student continues by observing different types of problems associated with spending large amounts of time logged into FB. For example, she notes that time spent logged 
onto FB may take time away from important academic responsibilities such as studying. As shown here, some students recognize the pervasiveness of $\mathrm{FB}$, and the possible consequences of over-exposure (i.e., impaired academic achievement). In a study at the University of Illinois, the vast majority of those surveyed (i.e., over $75 \%$ ) signed in $1-4$ times a day or more. In some interviews, participants reported keeping the website open in a browser almost all of the time they are using a computer (http://www.thefacebookproject.com/). As shown by the information above, research should more thoroughly examine the impact of FB on college life and academics because of its popularity, and the sheer amount of time that college students spend not only online, but also using FB.

In this primarily explorative study, an attempt was made to examine whether differences exist in the academic performance of college student FB users and nonusers. As implicated above and found in previous research, social networking via the computer (e.g., instant messaging) represents computer time for young individuals, because this activity is engaged in parallel with other computing activities such as doing homework (Grinter \& Palen, 2002). Assuming that FB use is not a "separate" activity, but rather something that students carry out while studying or while attending a lecture or workgroup, the negative relationship found in the current study might be an indication of a deleterious effect of trying to implement these two processes simultaneously (i.e., multitasking).

\section{Method}

\section{Participants}

Data were collected from 102 undergraduate and 117 graduate students at a large, public Midwestern university $(N=219)$. The sample consisted of $87(39.7 \%)$ male participants, and 132 female participants (60.3\%). The majority of participants identified themselves as Caucasian 
(73.1\%), with the next largest group identified as Asian (11.9\%). Other ethnicities represented include African-American (7.8\%), Bi-racial (3.2\%), Hispanic (2.3\%), Multi-racial (.9\%), and Other (.9\%). Participants were predominantly traditional college students with undergraduate $(46.6 \%)$ and graduate $(53.4 \%)$ students having a mean age of approximately $22.06(S D=3.72)$ and $30.29(S D=7.03)$, respectively.

\section{Measure}

A survey was developed containing five sections of closed-response (e.g., Yes/No and Likert-type scaling) and open-response items. Section 1 of the instrument asked respondents to provide demographic information (e.g., age, rank in school, major). Section 2 invited students to provide academic information (e.g., GPA, hours spent studying, extracurricular involvement). Section 3 asked about computer and Internet use (e.g., hours spent on the Internet, computer familiarity). The fourth section was specific to FB-use (e.g., hours of FB use, number of groups and applications used). Finally, the fifth section solicited information related to student perceptions of the impact of FB on their own academic achievement. Validity evidence for the instrument was provided by reviewing the questionnaire for the following: (1) Clarity in wording, (2) Relevance of the items, (3) Use of Standard English, (4) Absence of biased words and phrases, (5) Formatting of items, and (6) Clarity of the instructions (Fowler, 2002). Two faculty and two graduate students were asked to use these guidelines to review the instrument. Based on the reviewers' comments, the instrument was revised prior to administration.

\section{Procedure}

Participants were recruited by visiting scheduled classes and asking for volunteers to complete surveys in the summer and fall quarters of 2008. Permission from instructors was obtained prior to visiting the classes. Thus, the sampling method began as a convenience sample, 
which eventually developed into snowball sampling (Goodman, 1961) as more instructors recommended other instructors who were willing to participate in the study. A script to introduce the study, explain the consent process, and recruit participants was followed. A description of the instructions was also included at the top of the survey. The survey took approximately $20-25$ minutes to complete. Students completed and returned the survey at the time of recruitment.

\section{Analysis}

Data analysis was both quantitative and qualitative. Quantitative data (e.g., means, standard deviations, frequencies, percentages) were analyzed using Statistical Packages for the Social Sciences (SPSS) version 17.0 (SPSS, 2009). Aside from basic descriptive analyses, the main analytic technique implemented was a multivariate analysis of variance (MANOVA), which was used to examine the relationship between FB use and academic performance. Openresponse items were analyzed using Qualitative Data Analysis (QDA); based on an interpretive philosophy (Caudle, 2004). The main idea behind QDA is to examine the meaningful and symbolic content of qualitative data in order to identify someone's interpretations. Caudle's framework for QDA involves two major sub processes: (1) data reduction and pattern identification, and (2) producing objective analytic conclusions and communicating them. Data for each open-response item were reduced to the major themes and patterns within these themes were identified. Conclusions were drawn based on these main themes and patterns. In the current study, the authors conducted the data reduction process separately, and convened to compare their individual results. Major themes identified by both authors were interpreted further and reported. The use of two individual coders engaged in the QDA process added to the reliability and validity of the results and conclusions. In the following section of results, the sample will be 
delineated using basic descriptive analyses, followed by the MANOVA results, and a qualitative examination of some of the open-ended questions to support the results found in the MANOVA.

Results

\section{Descriptives}

Approximately $43.8 \%$ of the entire sample $(N=219)$ were junior and senior undergraduate students $(n=96)$ and $53.4 \%$ were graduate students $(n=117)$, with the remainder being freshmen and sophomores. This was not seen as a problem since in this way we hope to have precluded the possibility of an effect of spurious factors such as acclimatization to a new (i.e., university) environment in freshman, as well the effects of changing majors, which is often done either in the freshman year or between the end of the freshman year and the beginning of the second semester of the sophomore year (Ciavarri, 2008; Kramer, Higley, \& Olsen, 1994). Of the graduate students, $48.7 \%$ were Masters and $41.9 \%$ were Doctoral students. Graduate professional students (e.g., Education Administration, Law, Principal Licensure) accounted for only $9.4 \%$ of the sample. The majority of majors represented in the sample were Humanities and Social Sciences majors (72.6\%), followed by Medical and Allied Medical Professions majors (15.5\%), and the remaining students were either Business majors (5.9\%) or STEM majors (Science, Technology, Engineering, and Mathematics; 5.9\%). The overwhelming majority of the sample was full-time students $(81.7 \%)$, with $18.3 \%$ claiming to be part-time students.

\section{MANOVA Results}

In this exploratory and descriptive study, the relationship between academic performance variables and $\mathrm{FB}$ users and nonusers was examined. Before conducting the MANOVA, missing data and multivariate and univariate outliers were examined and assumptions were checked. Additionally, ordinal variables (i.e., Likert scaling) were used to define the dependent variables 
(i.e., GPA and hours spent studying per week). Likert/Ordinal variables are very commonly used with interval procedures, provided the scale item has at least 5 and preferably 7 categories (Binder, 1984). Both GPA and hours spent studying have at least 5 categories. Thus, in regard to using MANOVA, which assumes at least interval data for the dependent variables, Type I and Type II errors should not be inflated dramatically (Kim, 1975).

In examining for outliers and missing data, for GPA, 10 cases were missing. In these cases, students claimed not to have a GPA at the time of questionnaire completion. These cases were, thus, removed from further analyses $(N=209)$. Of the remaining GPA cases, analysis revealed no outliers. The GPA variable scale ranged from 0 to 4 (i.e., $0=1.99$ and below, $1=2.0-2.49,2=2.5-2.99,3=3.0-3.49,4=3.5-4.0)$. No outliers were present on the 'hours spent studying' variable where the scale was: (1) $0=$ less than 1 hour, (2) $1=1-5$ hours, (3) $2=6-10$ hours, (4) $3=11-15$ hours, and (5) $4=16$ or more hours.

The independence assumption was checked using a residual versus group plot for each grouping variable (i.e., FB use, student status, and major category). According to the graphs, the assumption was met. Histograms were generated for each dependent variable and also within each grouping variable to examine the data for normality. All histograms did not appear to be normally distributed; however, this is to be expected with ordinal/Likert data, and also considering grade inflation in GPA data (Astin, 1998; Bartlett \& Wasley, 2008). GPA was significantly negative skewed, and hours spent studying appeared to be positively skewed. When separated by each grouping variable, the results were the same as above. Thus, the distributions for the dependent variables were non-normal, and results should be interpreted with caution. Finally, Box's test indicated that the homogeneity of covariance assumption was not met $(p<.001)$. For the univariate results using Levene's test, the homogeneity of variance 
assumption was also not met for GPA $(p<.001)$, but was upheld for hours spent studying $(p=.019)$.

A three-factor MANOVA $(\alpha=.01)$ was performed on the dependent variables GPA and hours spent studying. The factors included FB use (yes / no), student status (undergraduate / graduate), and university major (humanities and social sciences / other). The multivariate main effect was statistically significant for both FB use and student status (Wilks' $\Lambda=.762$, $F=31.174, d f=2,200, p<.001$ for FB use; Wilks' $\Lambda=.933, F=7.144, d f=2,200, p=.001$ for student status). Univariate ANOVAs were conducted using an alpha level of .01 applying the Bonferroni correction (i.e., $\alpha=.005$ ). For FB use, the ANOVAs for GPA and hours spent studying per week were significant $(F=12.307, d f=1,201, p=.001$ and $F=55.329, d f=1$, $201, p<.001$, respectively). For student status, only GPA was statistically significant $(F=13.812, d f=1,201, p<.001)$.

From the ANOVAs for FB use, the groups were significantly different with FB users reporting a lower mean GPA than nonusers $(M=3.06, S E=.08 ; M=3.82, S E=.05$, respectively). For hours spent studying per week, FB users reported studying fewer hours per week on average than nonusers $(M=1.47, S E=.07 ; M=2.76, S E=.12$, respectively). The FB groups were also significantly different on time spent studying, with FB users reporting studying in the 1-5 hours/week range and the nonusers in the 11-15 hours/week range. The ANOVA for student status indicated significant differences on GPA between undergraduate and graduate students with graduate students reporting a higher mean in the $3.5-4.0$ range than undergraduates in the $2.5-3.0$ range $(M=3.74, S E=.05 ; M=2.85, S E=.09$, respectively). In the multivariate and univariate models, the two- and three-way interactions were not significant. Thus, at the univariate level, the relationship between FB use and GPA and hours spent studying 
does not depend on whether the student is an undergraduate or graduate student. Similarly, the relationship between FB use and GPA and hours spent studying per week does not depend on the major of the student (i.e., whether the student is a humanities and social science major or other major such as STEM, medical, or business).

\section{Other Descriptive Results}

In the sample without outliers, FB users $(n=141)$ and nonusers $(n=68)$ reported comparable percentages of average daily Internet use with between 1 and 2 hours per day as the highest category endorsed (42.6\% for both). The overwhelming majority of FB users claimed to visit academically-related $(90.8 \%)$ and non-related (100\%) websites in the course of their studies. Specific to FB use, $66 \%$ claimed to use their accounts either daily or multiple times per day, with $22.7 \%$ claiming to use their account on a weekly basis. If the FB user uses her/his account either daily or multiple times per day, $28.4 \%$ claimed to spend less than 15 minutes/day on the website, with the next highest percentage (24.1\%) claiming to spend between 45 minutes and 1 hour/ day. Approximately $81 \%$ of users are members of FB groups, with $87.1 \%$ using various applications on FB (e.g., poke, picture uploads) lasting for several minutes to hours per week.

Outside of Internet and FB use, $40.4 \%$ of FB users $(n=141)$ claimed spending 16 or more hours per week in paid work, with the next highest majority claiming to spend no time in paid work (17.7\%). In extracurricular involvement, $40.4 \%$ of FB users claim to be involved in such activities, with the majority only dedicating approximately 5 hours per week or less $(85.1 \%)$. The majority of students who claimed involvement in such activities listed on average more than two clubs or groups. Compared to FB users, $77.9 \%$ of the 68 nonusers claimed spending 16 or more hours per week in paid work. In extracurricular involvement, only $17.6 \%$ of 
Facebook ${ }^{\circledR}$ and Academic Performance 23

nonusers claim to be involved in such activities, with the majority only dedicating approximately less than 1 hour per week $(88.2 \%)$. The majority of students who claimed involvement in such activities listed on average only one club or group.

\section{Qualitative Results}

Qualitative survey data was also investigated. Students were asked whether they feel that FB has had an impact on their academic performance, and why they feel this way. The question was purposely left open and vague to elicit a range of explanations. The majority of FB users $(73.8 \% ; n=104)$ claimed that they feel that it does not have an impact, with the remainder $(26.2 \% ; n=37)$ reporting that they feel that FB has an impact on their academic performance (i.e., positive and negative directions combined). As stated, the question was intentionally openended (i.e., "Has Facebook had an impact on your academic performance?"), so that the student could choose to either give a positive or a negative direction in follow-up questions (i.e., "If yes, how" and "If no, why not?"). In those qualitative follow-up questions, 35 participants included a written explanation of why they feel that FB has an impact, with $74.3 \%(n=26)$ indicating a negative impact, and $25.7 \%(n=9)$ a positive impact. The content of these responses is included below.

Content analysis of the participants who responded that FB does not have an impact on their academic performance revealed common themes. Some FB users reported not using it frequently enough for it to have an impact and emphasized that academics, for them, were a priority. Conversely, FB users reporting a negative impact (i.e., 74.3\% of the 35 participants claiming that FB has an impact) stated that they procrastinated and were distracted from school work, and that they had poor time-management skills. A positive impact was also noted in responses (i.e., $25.7 \%$ of the 35 participants claiming that FB has an impact), including 
statements of support for FB as a networking tool to form study groups or encouraging fellow students through various communication applications.

\section{Discussion and Conclusions}

The three main purposes of this exploratory investigation were to (1) examine whether differences exist in the academic performance of college student FB users and nonusers, (2) describe a small sample of FB users and nonusers at one Midwestern university, and (3) examine FB users reasons for notions of impact or lack thereof of FB use on their academic performance.

With respect to differences on academic performance, the analyses revealed three major groups of findings: First, FB users and nonusers were significantly different from each other with FB users reporting both a lower mean GPA and spending fewer hours per week studying on average than FB nonusers, though the amount of total time spent on the Internet did not differ between the groups (see the next paragraph). Clearly, there is a difference between the study strategies of FB users and nonusers. Second, significant differences were found between undergraduate and graduate students for GPA with graduate students reporting a higher mean GPA than undergraduates. Finally, the higher-order interactions were not significant (i.e., the two- and three-way interactions) suggesting that at the univariate level, the relationship between FB use and GPA and hours spent studying is sustained regardless of student status (i.e., undergraduate or graduate student), or the major of the student (i.e., whether the student is a humanities and social science major or other major such as STEM, medical, or business).

For the second main goal, FB users and nonusers reported comparable average daily Internet use (i.e., between 1 and 2 hours per day as the highest category endorsed). In other words, FB use did not add time used on the Internet, possibly to the detriment of available study time. Also, $66 \%$ of FB users claimed to use their accounts either daily or multiple times per day, 
Facebook ${ }^{\circledR}$ and Academic Performance 25

with many reporting either spending less than 15 minutes/day on the website, or spending between 45 minutes and 1 hour/day. Finally, more nonusers spend 16 or more hours per week in paid work compared to FB users, and more FB users reported being involved in extracurricular activities, dedicating more hours per week to such activities, and reporting on average more than two clubs or groups in which they are involved.

These findings can suggest a number of things, specifically, that certain personalities are more inclined to use FB or not use FB. For example, it appears that FB users are more involved in extracurricular activities, suggesting more social extraversion; thus, it makes sense that these individuals would use FB to perhaps maintain or expand their social networks, and help organize specifics of extracurricular activities. Additionally, more FB nonusers report working more hours per week in paid work, which suggests that these individuals are perhaps too busy with their academic/professional lives to engage in and maintain an online social profile, or that online social engagement is not a priority. This is a topic that could use specific future research.

Finally, the study also yielded some interesting qualitative results. First, the majority of FB users reported that it did not impact their academic performance to not using FB frequently enough for such an effect to occur. They also emphasized that academics were a priority for them. Second, of the FB users reporting an impact, the majority indicated a negative impact citing procrastination behavior on their part. These students reported having poor timemanagement skills and that FB use allows them to put off studying while not giving them the feeling that they are "not working"; evidenced by their statements that FB was beneficial to their learning (i.e., of the FB users reporting an impact, respondents claimed to use it as a networking tool for academic purposes). Clearly, they place the locus of control of their FB use and its effects outside of FB and in their own personalities. 
The main finding here is that the data shows a significant negative relationship between FB use and academic performance. FB users reported lower mean GPAs and reported spending fewer hours per week studying on average than FB nonusers. As noted previously, assuming that FB use is something that students do concurrently with studying or other activities that may enhance their academic performance, the negative relationship found might be an indication of a deleterious effect of trying to implement these two processes at the same time. Although this was not measured directly in the current study, the literature base discussed earlier in this article suggests that trying to implement two cognitive processes simultaneously can have a negative impact on both the effectiveness and the efficiency of carrying out the tasks. Conceivably, any task that is implemented at the same time as studying may have this same effect, though some study tasks - such as inquiry learning - require the simultaneous conducting of tasks. Kirschner, Sweller, and Clark (2006) documented this decisively. Thus, the current study is not implicating FB as the root of any evil, or that if a student uses FB, his/her academic performance may suffer.

The results, however, do bring to light a number of unanswered questions in this area of study, specifically that current technological trends that, with computer and Internet accessibility at an all-time high on college campuses, may make it easier to engage in multiple activities while trying to study. Also, modern educational gurus such as Veen and Vrakking (2006) even promote this. As availability and access to affordable technology increases on campuses, and students' comfort level and experience in using technology also escalates, it is inevitable that the use of FB and other Web 2.0 applications and social networking software will increase as well.

Other interesting findings in the study only highlight the number of questions that remain unanswered. For example, FB users and nonusers reported comparable percentages of average daily Internet use; however, the nature of the Internet activities was not delineated in the survey. 
Further examination of whether the time spent on the Internet was or was not related to studying or specific academic content is restricted. A more thorough examination of Internet activities may help explain the interesting findings that the majority of FB users and nonusers reporting using comparable percentages of daily Internet use, yet the amount of time spent studying differs dramatically (i.e., and GPA). For example, do the students logging 1 to 2 hours per day on the Internet access and stay online in one full block of time, or is 1 to 2 hours per day spread out across several waking hours while students are engaged in other activities? How this has an impact on a student's study time is difficult to decipher without knowing the specifics of a student's Internet use. Another issue to consider is the difference in how the variables were measured in the survey. Hours spent studying was polled for weekly use, and Internet use was surveyed as a daily average. More specifically with regards to how students use the Internet, if a student is engaged in their daily Internet use in one block of time during the day, and that block of time is concurrent with study time, this may support the crux of the multitasking supposition in this article.

One question that comes to mind is if for the FB nonusers, time spent on the Internet, if not academically-related, would produce similar results as in the FB use GPA/study time relationship in the current study. If general Internet activity was done concurrently with studying, based in the multitasking literature, the logical answer would be yes. Also, related to this is that though total Internet time usage is equivalent, FB users spent less of the time remaining outside of class studying than nonusers. They also report spending more time on social extracurricular activities yet less time on working for pay. This opens the question of whether FB is a cause or is rather a result of the fact that FB users differ from non users in a fundamental way. 
Another interesting descriptive finding was that a strong majority of FB users claimed to use their accounts either daily or multiple times per day. One question that emerges from this is what exactly is meant by daily or multiple times per day. Does this indicate that FB users log onto FB and leave it open all day, or that they $\log$ in and out several times a day? Related to multitasking, does this mean that a user logs onto FB while studying, or begins studying while being logged on, leaving FB open the entire duration of study?

With respect to the qualitative results, it is interesting to note in that the majority of students claimed that using FB does not have an impact on their academic performance. This finding is in opposition to the MANOVA results, which suggests a relationship between the two variables. Although positive and negative impacts were cited, overall, students overwhelmingly avoided mentioning the possibility of FB negatively impacting their academics. Although direct causation cannot be inferred, the disconnect between the quantitative and qualitative results is cause for concern. Future research should perhaps consider utilizing focus groups of college students to garner more qualitative information that can be missed by using open-ended survey questions.

Limitations and future directions. Many limitations exist in the current study beginning with the sample being drawn from a population of students at a single, large, public, Midwestern university. Thus, the results may not be generalizable to students at other institutions or with other demographics. Second, the information produced from this study is descriptive and correlational, and causation cannot be inferred. Finally, the accuracy of respondents is questionable in reporting information on large survey studies such as this. For example, respondents were asked to recount how many hours per week he or she typically spends using the Internet, and the degree to which students may be able to accurately report such information 
is unclear. Future work should actually record logging data so as to determine the veracity of the self-report (though this could involve privacy issues).

Future research needs to further examine specifics of FB user and nonuser participation in paid work and extracurricular involvement. For example, with respect to paid work per week, it is conceivable that students working and attending college full-time may be too busy to maintain large social networks that may include friends at school and at work. This population may have little time for face-to-face socialization between all their responsibilities (e.g., attending classes, studying, working). Future research might consider examining the underlying reasons for these differences as well as the different kinds of paid jobs that students maintain while attending college, and the relationship between job type and SNS use.

With regards to extracurricular activities, future research could also examine why FB users report more extracurricular involvement. Such students (i.e., those who participate in extracurricular activities) may have extensive social networks including not only classmates, but also friends who share mutual interests through extracurricular activity participation. Thus, FB may be used by this group to maintain this extensive network of friends. Future research can investigate whether this is the case.

Finally, survey research in general is problematic for many reasons, namely the use of Likert/Ordinal data which can be difficult to use and interpret in many statistical analyses. Future directions for this particular study include using different analyses besides basic MANOVA tests such as regression or structural equation modeling. Furthermore, as noted previously, the use of survey data limits the conclusions that can be drawn from the results, and future research in general should consider using a more rigorous experimental design. These data are correlational, and it cannot be stated that FB use causes a student to study less hours per week or have a lower 
GPA. As noted above, if FB did not exist, these students might spend their time engaged in other activities that might interfere with studying.

The use of FB - and other social networking software - is a multifaceted phenomenon where there are many factors that can influence each other. This research only exposes the tip of this iceberg, but as with all icebergs - though we cannot see what is under the tip - we know it's there and we know that it can wreak havoc if not heeded. 


\section{References}

American Psychological Association (March 20, 2006). Multitasking = Switching Costs. Available at http://www.apa.org/research/action/multitask.aspx.

Astin, A.W. (1998). The changing American college student: Thirty-year trends, 1966-1996. The Review of Higher Education, 21, 115-135.

Austin, M. (2009, June). Texting while driving: How dangerous is it? Car and Driver. Retrieved from http://editorial.autos.msn.com/article.aspx?cp-documentid=1076338\&topart=safety via http://www.caranddriver.com.

Barratt, W., Hendrickson, M., Stephens, A., \& Torres, J. (2005). Thefacebook.com: Computer mediated social networking. Student Affairs Online, 6(1), 1-5.

Bartlett, T., \& Wasley, P. (2008). Just say 'A': Grade inflation undergoes reality check. The Chronicle of Higher Education, 55(2), A1-A12.

Beastall, L. (2008). Enchanting a disenchanted child: Revolutionizing the means of education using information and communication technology and e-learning. British Journal of Sociology of Education, 27(1), 97-110.

Binder, A. (1984). Restrictions on statistics imposed by method of measurement: Some reality, some myth. Journal of Criminal Justice, 12, 467-481.

Boyd, D. M., \& Ellison, N. B. (2008). Social network sites: Definition, history, and scholarship. Journal of Computer-Mediated Communication, 13, 210-230.

Bullen, M., Morgan, T., Belfer, K., \& Qayyum, A. (2008). The digital learner at BCIT and implications for an e-strategy. Paper presented at the 2008 Research Workshop of the European Distance Education Network (EDEN) "Researching and promoting access to 
education and training: The role of distance education and e-learning in technologyenhanced environments", Paris, France, October 20-22.

Caudle, S. L. (2004). Qualitative data analysis. In J. S. Wholey, H. P. Hatry, \& K. E. Newcomer (Eds.). Handbook of practical program evaluation ( $2^{\text {nd }}$ ed., pp. 417-438). San Francisco: Jossey-Bass.

Ciavarri, A. (January 15, 2008). Students change majors frequently. The Bona Venture. From http://media.www.thebv.org/media/storage/paper1111/news/2008/01/25/News/Students. Change.Majors.Frequently-3167371.shtml

Clark, R. E. (1989). When teaching kills learning: Research on mathematics. In H. N.Mandl, N. Bennett, E. de Corte and H. F. Freidrich, Learning and Instruction. European Research in an International Context. Volume II. London: Pergamon Press Ltd.

DeBell, M., \& Chapman, C. (2006). Computer and Internet use by students in 2003 (NCES 2006-065). U.S. Department of Education. Washington, DC: National Center for Education Statistics.

Ebner, M., Schiefner, M., \& Nagler, W. (2008). Has the Net-Generation arrived at the university? = oder der Student von Heute, ein Digital Native? [or Contemporary student a Digital Native?]. In S. Zauchner, P. Baumgartner, E. Blaschitz, \& A. Weissenbäck (Eds.), Medien in der Wissenschaft [Media in science], volume 48, 113-123. Muenster, Germany: Waxmann Verlag.

Espinosa, L. M., Laffey, J. M., Whittaker, T., \& Sheng, Y. (2006). Technology in the home and the achievement of young children: Findings from the Early Childhood Longitudinal Study. Early Education and Development, 17, 421-441. 
Fox, A. B., Rosen, J., \& Crawford, M. (2008). Distractions, distractions: Does instant messaging affect college students' performance on a concurrent reading comprehension task? Cyberpsychology and Behavior, 12, 51-53.

Gemmill, E., \& Peterson, M. (2006). Technology use among college students: Implications for student affairs professionals. NASPA Journal, 43, 280-300.

Gonzalez, N. CheckFacebook.com: Facebook marketing statistics, demographics, reports, and news. Accessed August 8, 2009.

Goodman, L. A. (1961). Snowball sampling. Annals of Mathematical Statistics, 32, 148-170. doi:10.1214/aoms/1177705148

Grinter, R., \& Palen, L. (2002, November). Instant Messaging in teen life. Proceedings of the ACM Conference on Computer-Supported Work, New Orleans, LA.

Harp, S. F., \& Mayer, R. E. (1997).The role of interest in learning from scientific text and illustrations: On the distinction between emotional interest and cognitive interest. Journal of Educational Psychology, 89(1), 92-102.

Hunley, S. A., Evans, J. H., Delgado-Hachey, M., Krise, J., Rich, T., \& Schell, C. (2005). Adolescent computer use and academic achievement. Adolescence, 40, 307-318.

Karpinski, A. C. (2009). Media sensationalization of social science research: Social-networking insites. Teachers College Record. http://www.tcrecord.org/Content.asp?ContentID $=15642$

Karpinski, A. C. \& Duberstein, A. (2009, April 16). A description of Facebook use and academic performance among undergraduate and graduate students. Poster presented at the meeting of the American Educational Research Association, San Diego, CA. 
Kennedy, G., Dalgarno, B., Gray, K., Judd, T., Waycott, J., Bennett, S., Maton, K., Krause, K.L., Bishop, A., Chang, R., \& Churchward, A. (2007). The net generation are not big users of Web 2.0 technologies: Preliminary findings. In R. J. Atkinson, C. McBeath, S. K. A. Soong,. \& C. Cheers (Eds.), ICT: Providing choices for learners and learning. Proceedings of ASCILITE 2007 Conference. Centre for Educational Development, Nanyang Technological University, Singapore. [Online] Retrieved July 31, 2009 from http://www.ascilite.org.au/conferences/singapore07/procs/kennedy.pdf

Kim, J. O. (1975). Multivariate analysis of ordinal variables. American Journal of Sociology, 81, 261-298.

Kirschner, P. A., Sweller, J. \& Clark, R. E (2006). Why minimal guidance during instruction does not work: An analysis of the failure of the constructivist, discovery, problem-base, experiential, and inquiry-based teaching. Educational Psychologist 14(2), 75-86.

Kolek, E. A., \& Saunders, D. (2008). Online disclosure: An empirical examination of undergraduate Facebook profiles. NASPA Journal, 45(1), 1-25.

Kramer, G. L., Higley, H. B., \& Olsen, D. (1994). Changes in academic major among undergraduate students. College and University, 69(2), 88-98.

Kubey, R. W., Lavin, M. J., \& Barrows, J. R., (2001). Internet use and collegiate academic performance decrements: Early findings. Journal of Communication, 51, 366-382.

Kvavik, R. (2005). Convenience, communications, and control: How students use technology. In D. Oblinger, \& J. Oblinger (Eds.), Educating the Net Generation (Chapter 7) [e-book]. Retrieved July 31, 2009 from http://www.educause.edu/educatingthenetgen/5989 Lei, J., \& Zhao, Y. (2005). Technology uses and student achievement: A longitudinal study. Computers \& Education, 49, 284-296. 
Lipsman, A. (2007a, June). Facebook sees flood of new traffic from teenagers and adults. ComScore. Retrieved November 13, 2009 from http://www.comscore.com/press/release.asp?press=1519

Margaryan, A., \& Littlejohn, A. (2008). Are digital natives a myth or reality? Students' use of technologies for learning. Final draft (December 11, 2008) available online at http://www.academy.gcal.ac.uk/anoush/documents/DigitalNativesMythOrRealityMargaryanAndLittlejohn-draft-111208.pdf

Mark, G., Gudith, D., \& Klocke, U. (2008). The cost of interrupted work: More speed and stress. Proceeding of the twenty-sixth annual SIGCHI conference on Human factors in computing systems Association for Computing Machinery, April 5-10, 2008, Florence, Italy [doi $>10.1145 / 1357054.1357072]$

National Telecommunications and Information Administration- NTIA (2000). Falling through the Net: Defining the digital divide: A report on the telecommunications and information technology gap in America. U.S. Department of Commerce. National Telecommunications and Information Administration. Washington, DC: NTIA. Available at http://search.ntia.doc.gov/pdf/fttn00.pdf

Ophira, E., Nass, C., \& Wagner, A. D. (2009). Cognitive control in media multitaskers. Proceedings of the National Academy of Sciences of the United States of America, 106(33), September 15, 2009. Available at http://www.pnas.org/content/106/37/15583

Owen, M (2004a). Just a tool? In M. Monteith (Ed.), ICT for Curriculum Enhancement. Bristol, UK: Intellect.

Owen, M (2004b). The Myth of the Digital Native. www.futurelab.org.uk/viewpoint/art26.htm 
Pasek, J., More, E., \& Hargittai, E. (2009, May). Facebook and academic performance: Reconciling a media sensation with data. First Monday, 14(5).

Peterson, L. R., \& Peterson, M. J. (1959). Short-term retention of individual verbal items. Journal of Experimental Psychology, 58, 193-198.

Prenksy, M. (2001). Digital natives, digital immigrants. On the Horizon, 9(5), 1-6.

Prensky, M. (2003). Digital game-based learning. ACM Computers in Entertainment, 1(1), 1-4.

Rosen, L. D. (2007). Me, MySpace, and I: Parenting the net generation. New York: Palgrave Macmillan.

Rosen, L. D. (2009). Welcome to the iGeneration. Paper presented in the symposium The iGeneration: Media use, health, and English literacy at the Western Psychological Association Convention, Portland, OR, April 23-26, 2009.

Statistical Packages for the Social Sciences 17.0 for Windows. (2009). Chicago, IL: SPSS, Inc.

Stevens, J. P. (2002). Applied multivariate statistics for the social sciences $\left(4^{\text {th }}\right.$ ed.). Mahwah, NJ: Erlbaum.

Strayer, D. L. \& Drews, F. A. (2007). Multi-tasking in the automobile. In A. Kramer, D. Wiegmann, \& A. Kirlik (Eds.) Applied attention: From theory to practice (pp. 121-133). New York: Oxford University Press.

Strayer, D. L., Drews, F. A., \& Crouch, D. L. (2006). A comparison of the cell phone driver and the drunk driver. Human Factors, 48, 381-391.

Strayer, D. L., Drews, F. A., \& Johnston, W. A. (2003). Cell phone induced failures of visual attention during simulated driving. Journal of Experimental Psychology: Applied, 9, 2352. 
Sweller, J., Kirschner, P. A., \& Clark, R. E. (2007). Why minimal guidance during instruction does not work: A reply to commentaries. Educational Psychologist, 47(1), 115-121.

Tapscott, D. (1997). Growing up digital: The rise of the net generation. New York: McGrawHill.

Vanden Boogart, M. R. (2006). Uncovering the social impacts of Facebook on a college campus. Unpublished Masters Thesis, Kansas State University.

Veen, W., \& Vrakking, B. (2006). Homo Zappiens: Growing up in a digital age. London, Network Continuum Education.

$\mathrm{Xu}, \mathrm{L}$. (2008). Impact of simultaneous collaborative multitasking on communication performance and experience. Unpublished Dissertation, The Ohio State University.

Zuckerberg, M. (2005). Thefacebook.com. Retrieved June 13, 2008 from

http://thefacebook.com/about.php. 
Facebook $^{\circledR}$ and Academic Performance 38

Figure Captions

Figure 1. Facebook ${ }^{\circledR}$ Statistics on December 7, 2009. 


\section{Figure 1}

\section{facebook}

Press Room

Blog | About | \$ Press Releases R5S

\section{Statistics}

Company
Figures
$50 \%$ of our active users log on to Facebook in any given day
More than 35 million users update their status each day
More than 55 million status updates posted each day
More than 2.5 billion photos uploaded to the site each month
More than 3.5 billion pieces of content (web links, news stories, blog posts, notes,
photo albums, etc.) shared each week
More than 3.5 million events created each month
More than 1.6 million active Pages on Facebook
More than 700,000 local businesses have active Pages on Facebook
Pages have created more than 5.3 billion fans

Average User Figures
Average user has 130 friends on the site

Average user sends 8 friend requests per month

Average user spends more than 55 minutes per day on Facebook

Average user clicks the Like button on 9 pieces of content each month

Average user writes 25 comments on Facebook content each month

Average user becomes a fan of 2 Pages each month

Average user is invited to 3 events per month

Average user is a member of 12 groups 